Original Article

\title{
Histomorphometrical study of the tongue epithelium of the peregrine falcon (Falco peregrinus)
}

\author{
Estudo histomorfométrico do epitélio da língua do falcão peregrino (Falco peregrinus)
}

\author{
F. A. Al-Nefeiy ${ }^{a *}$ (1) \\ aUniversity of Jeddah, College of Science, Department of Biology, Jeddah, Saudi Arabia
}

\section{Abstract}

The aim of this study is to examine the dorsal lingual epithelium of the peregrine falcon (Falco peregrinus) of the family Falconidae. The tongue in its dorsal, lateral and ventral surfaces is covered with a non-keratinized multilayered stratified squamous epithelium. Lamina propria is present beneath the epithelial layers. Morphometrically, thickness of the apex tongue epithelium is more than that in the tongue body. Thickness of the ventral surface of the tongue is less than that in the dorsal one. Thickness of the lateral surface of the tongue was thicker than that in the ventral one and tongue body. Large and small conical papillae appeared on the posterior dorsal surface of the lingual body. There are lingual glands in certain areas of tongue body with numerous openings through the dorsal surface.

Keywords: falcon, tongue, epithelium, histomorphometry, feeding.

Resumo

O objetivo deste estudo é examinar o epitélio lingual dorsal do falcão peregrino (Falco peregrinus) da família Falconidae. A língua em suas superfícies dorsal, lateral e ventral é coberta por um epitélio escamoso estratificado de múltiplas camadas não queratinizado. A lâmina própria está presente abaixo das camadas epiteliais. Morfometricamente, a espessura do epitélio do ápice da língua é maior do que a do corpo da língua. A espessura da superfície ventral da língua é menor do que a dorsal. A espessura da face lateral da língua foi mais espessa do que na ventral e no corpo da língua. Papilas cônicas grandes e pequenas apareceram na superfície posterior dorsal do corpo lingual. Existem glândulas linguais em certas áreas do corpo da língua com numerosas aberturas na superfície dorsal.
\end{abstract}

Palavras-chave: falcão, língua, epitélio, histomorfometria, alimentação.

\section{Introduction}

There is a correlation between bird's diets and the lingual epithelium morphology. Several studies showed that the structure of the bird's tongue depend on the feeding habit and consumed food (Jackowiak and Godynicki 2005; Jackowiak and Ludwig 2008; Tivane 2008; Taki-El-Deen, 2017). Many authors revealed that there is a close correlation of the structure of the surface epithelium with the style of food swallowing and the kind of food (Mclelland, 1975; Iwasaki et al., 1997; Homberger and Brush, 1986; Shawki and Abdel-Rahman, 1998). Birds tongue in their dorsal and a layer of stratified squamous epithelium covers ventral surfaces. This layer may be keratinized or non-keratinized according to the bird food intake. Erdoğan et al.(2012b) stated that the thickness of keratinization of the postero-dorsal and lateral tongue surfaces of domestic birds is less. Tongue dorsal and ventral epithelium in ratites is non-keratinized and slightly thicker than the ventral one (Jackowiak and Ludwig, 2008; Crole and Soley, 2009b; Carlesso Santos et al., 2011). Iwasaki et al. (1997) stated that the lingual papillae in birds consumed hard foods such as grains do as teeth and hold the food at the dorsal surfaces of the tongue. Iwasaki (1992) illustrated that lingual glands are present in many birds and absent in others such as the pelicanns. Salivary glands are well developed in granivorous and insectivorous and in birds that consumed soft diet such as piscevorous, they are less developed.

The aim of this study was to describe the histomorphometry of the tongue epithelium of the peregrine falcon using light and scanning electron microscopy.

\section{Materials and Methods}

\subsection{Microscopic studies}

Adult healthy birds were killed by neck dislocation. For routine light microscopy, Samples from the tongues apex and tongue body were taken and left in a $10 \%$ neutral

*e-mail: faalnefaie@uj.edu.sa

Received: October 13, 2020 - Accepted: November 24, 2020 
buffered formalin for $24 \mathrm{~h}$ for fixation, then the samples were dehydrated using ethanol, followed by clearing in xylene and then impregnated with soft paraffin and left to harden to obtain paraffin blocks. The blocks were then cut serially into thin sections of about 5-7 $\mu \mathrm{m}$. thick using a microtome and then mounted on dry, clean glass slides. The slides were stained with hematoxylin and eosin (H\&E) stain.

\subsection{Scanning electron microscope study}

In each bird, one tongue was fixed in 5\% gluteraldehyde, post fixed in $1 \%$ osmium tetroxide for two hours. Thereafter, the specimens were then washed in $0.2 \mathrm{M}$ phosphate buffer solution for several times before treatment with $3 \mathrm{~N}$ hydrochloric acid at $60^{\circ} \mathrm{C}$ for 30 minutes in order to remove the mucus from the tongue surface. The samples were dehydrated in an ascending series of ethanol. After critical drying point, the specimens were mounted and coated with gold, using a Jeol vaccum unit. The specimens were then observed under JEOL scanning electron microscope (JSM-5400V)

\subsection{Morphometrical study}

Five slides were measured in the regions of each tongue bird (five section for each slide). In each tongue region, thick epithelial measurement were obtained. Sections were examined and measured using an image analysis system (MOTIC Image Plus 2.0 software) connected with research microscope equipped with digital camera.

\section{Results}

\subsection{Microscopic observations}

Examination of the histological sections (see Figures 1A-D) obtained from the tongue of the Falcon (Falco peregrinus) showed that it is supported by a single oval shaped cartilagenous hyoid apparatus named paraglossale. Lingual muscle bundles are parallel to the long axis of the tongue. The dorsal, lateral and ventral surfaces of the tongue are covered with a non-keratinized multilayered stratified squamous epithelium. A common feature of both surfaces of the tongue is the presence of lamina propria, which is richly vascularized connective tissues just beneath the epithelial layers. The lingual glands are present beneath the dorsal lingual epithelium in the lingual body in different regions. The lingual glands are in tubuloalveolar type and their ducts open directly dorsally.
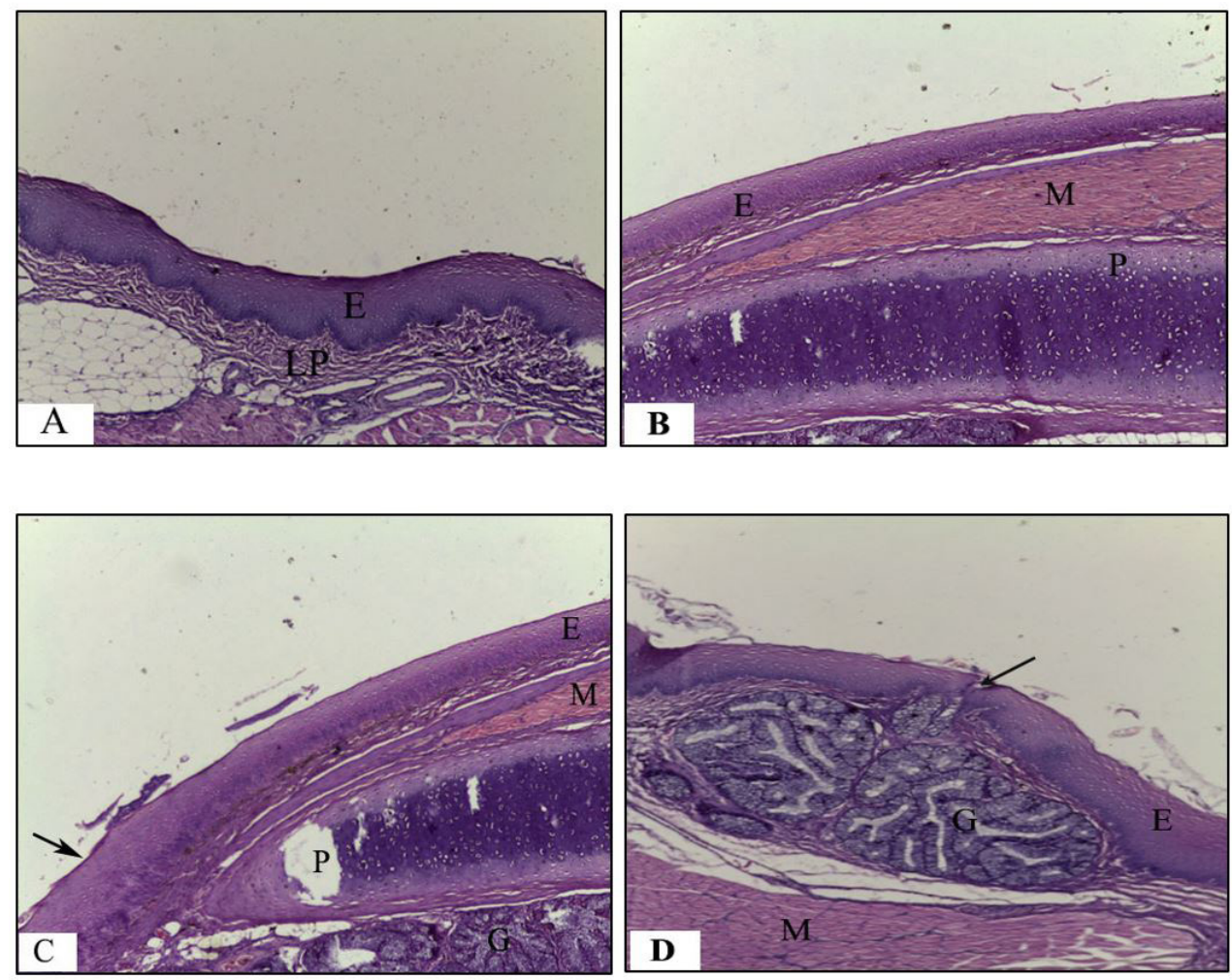

Figure 1. A. Photomicrograph of a transverse section of the lingual apex of the falcon showing the dorsal lingual epithelium (E) and lamina propria (LP). (X, 40). B. Photomicrograph of a transverse section of the lingual body of the falcon showing the dorsal lingual epithelium (E) lingual muscles (M) and paraglossum (P). (X, 40). C. Photomicrograph of a transverse section of the lingual body of the falcon showing the dorsal lingual epithelium (E), lingual muscles (M), paraglossum (P) and the lateral epithelium (arrow) (X,40). D. Photomicrograph of a transverse section of the lingual body of the falcon showing the dorsal lingual epithelium (E) lingual muscles (M), lingual glands ( $\mathrm{G}$ ) and opening of the lingual glands (arrow). (X, 40). 


\subsection{Scanning electron microscopy}

Scanning electron microscopic observations (see Figures $2 \mathrm{~A}-\mathrm{C}$ ) demonstrated that the lingual epithelium at dorsal surface of the tongue apex is in a carpet shape. Tongue dorsa epithelium of the lingual body is a flat smooth layer with lingual glands openings. There are two types of conical papillae, large conical papillae and small ones. All papillae are in conical shape, their tips are sharp and in a caudal direction and between the body and root of the tongue.

\subsection{Morphometrical observations}

The thickness of the epithelial measurements (see Table 1) revealed differences between different parts of the tongue. The epithelium of the apex of the tongue was thicker than that in the tongue body. At the dorsal surface, thickness of the apex epithelium was (548.6 \pm 83.4) $\mu \mathrm{m}$ while in the tongue body, the thickness was $(338.7 \pm 49.3) \mu \mathrm{m}$. Thickness of the ventral surface of the tongue $(293.9 \pm 39.4) \mu \mathrm{m}$ was less than that in the dorsal surface. Thickness of the lateral surface of the tongue $(478.2 \pm 56.8)$ was thicker than that in the ventral one and tongue body.

\section{Discussion}

The results of this study described the microscopic structure of the lingual epithelium and correlation between the structure of the tongue and the feeding habits. Thickness of lingual epithelium of birds are differ between different regions of the tongue according to the level of contact of this region with food consumed. Dorsal epithelium of the tongue apex in many birds is in a direct contact with consumed food and this can cause injuries during food swallowing. Therefore, lingual epithelium of tongue apex is thicker that of another tongue regions as in case of the falcon. The thick of keratinized epithelium depended on the type of food intake. Keratinization of
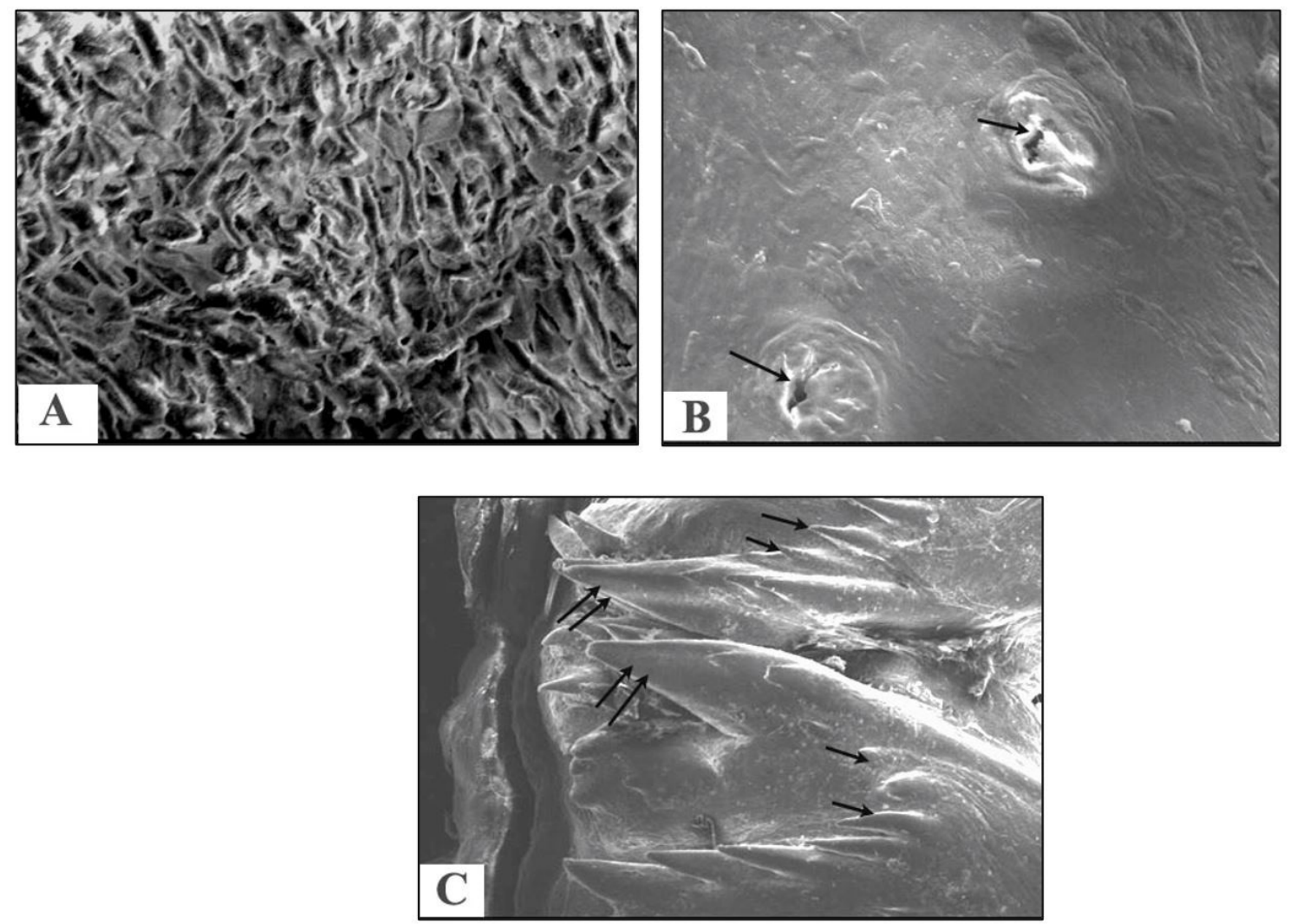

Figure 2. (A) Scanning electron micrograph of the dorsal surface of the lingual apex of the falcon showing that the lingual epithelium is in a carpet shape. (X,550); (B) Scanning electron micrograph of the dorsal surface of the lingual body of the falcon showing the opening of the lingual gland (arrows). (X,300); (C) Scanning electron micrograph of the dorsal surface of the lingual body of the falcon showing the small conical papillae (single arrow) and large conical papillae (double arrows). (X,27).

Table 1. Lingual epithelium thickness $(\mu \mathrm{m})$ of different regions of peregrine falcon. (Means \pm Standard Deviation).

\begin{tabular}{lcccc}
\hline & Tongue apex $(\mu \mathrm{m})$ & Tongue body $(\mu \mathrm{m})$ & Ventral surface $(\mu \mathrm{m})$ & Lateral surface $(\mu \mathbf{m})$ \\
\hline Means \pm standard deviation & $548.6 \pm 83.4$ & $338.7 \pm 49.3$ & $293.9 \pm 39.4$ & $478.2 \pm 56.8$ \\
\hline
\end{tabular}


the epithelium is more in granivorous and herbivorous birds and less in water habitats birds which feeds on wet food (Iwasaki, 2002; Jackowiak and Ludwig, 2008, Parchami et al., 2010; Skieresz-Szewczyk et al. 2014).). In this study, the non-keratinized epithelium thickness of the tongue in the peregrine falcon may adapted for mechanical protection (wet food of meat of small birds) that not need keratinization as in case of birds feeds on hard food (grains) which need keratinization to protect the epithelium. This result is in accordance with the emu tongue (Crole and Soley, 2008) and Muscovy duck (Igwebuike and Anagor, 2013b) in which the lingual epithelium is thick and non-keratinized. Many birds have well developed papillae such as owl and eagle which feed on small animals or fish and is not present in others which manipulate insects or plants such as ostrich and woodpecker (Emura and Chen, 2008; Emura et al., 2009). Caudally directed papillae help to transfer food in a direction from the mouth to the esophagus and stop regurgitation (Koolos, 1986).

(Iwasaki and Kobayashi, 1986) stated that there are caudally papillae between the tongue body and root of the chicken is in accordance with this study in peregrine falcon. Also, in long-legged buzzard (Erdo an et al., 2012a). Lingual glands are differing in birds. They well developed in birds that consumed dry food like seeds and less developed in birds that feeds on moist food (Whittow, 2000). Tongue birds may contain lingual glands in different regions such as in chukar partridge (Erdo an et al., 2012b). Lingual glands secrete mucous, which helps in moistening the food. The present work demonstrated that these glands are poor developed and present in certain areas on the tongue surface with many openings. Poorly developed lingual glands may be due to moist food of peregrine falcon.

In conclusion, this study showed that structures of the falcon tongue, epithelium, papillae and lingual glands are adapt to feeding habits.

\section{Acknowledgements}

The author would like to thank Deanship of Scientific Research, University of Jeddah for their kind help and assistance in preparing this study

\section{References}

CARLESSO SANTOS, T., YURI FUKUDA, K., PLÁCIDO GUIMARÃES, J., FRANCO OLIVEIRA, M., ANGELICA MIGLINO, M. and WATANABE, L.S., 2011. Light and scanning electron microscopy study of the tongue in Rhea americana. Zoological Science, vol. 28, no. 1, pp. 41-46. http://dx.doi.org/10.2108/zsj.28.41. PMid:21186946.

CROLE, M.R. and SOLEY, J.T. 2008. Histological structure of the tongue of the emu (Dromaius novaehollandiae). In Proceedings of the Microscopy Society of Southern Africa, 2008, Pretoria. Pretoria: Microscopy Society of Southern Africa, pp. 63.

CROLE, M.R. and SOLEY, J.T., 2009b. Morphology of the tongue of the emu (Dromaius novae-hollandiae).II. Histological features. The Onderstepoort Journal of Veterinary Research, vol. 76, no. 4, pp. 347-361. http://dx.doi.org/10.4102/ojvr.v76i4.18. PMid:21344785.
EMURA, S. and CHEN, H., 2008. Scanning electron microscopic study of the tongue in the owl (Strix Uralensis). Anatomia, Histologia, Embryologia, vol. 37, no. 6, pp. 475-478. http:// dx.doi.org/10.1111/j.1439-0264.2008.00871.x. PMid:19032633.

EMURA, S., OKUMURA, T. and CHEN, H., 2009. Scanning electron microscopic study of the tongue in the Japanese pygmy woodpecker (Dendrocopes kizuki). Okajimas Folia Anatomica Japonica, vol. 86, no. 1, pp. 31-35. http://dx.doi.org/10.2535/ ofaj.86.31. PMid:19522304.

ERDOǦAN, S., PÉREZ, W. and ALAN, A., 2012a. Anatomical and scanning electron microscopic investigations of the tongue and laryngeal entrance in the long-legged buzzard (Buteo rufinus, Cretzschmar, 1829). Microscopy Research and Technique, vol. 75, no. 9, pp. 1245-1252. http://dx.doi.org/10.1002/jemt.22057. PMid:22496047.

ERDOĞAN, S., SA־GSÖZ, H. and AKBALIK, M.E., 2012b. Anatomical and histological structure of the tongue and histochemical characteristics of the lingual salivary glands in the Chukar partridge (Alectoris chukar, Gray 1830). British Poultry Science, vol. 53, no. 3, pp. 307-315. http://dx.doi.org/10.1080/000716 68.2012.700507. PMid:22978586.

HOMBERGER, D.G. and BRUSH, A.H., 1986. Functional morphological and biochemical correlation of the keratinized structure in the African Grey parrot, Psittacus erithacus (Aves). Zoomorphology, vol. 106, pp. 103-114. http://dx.doi.org/10.1007/BF00312112.

IGWEBUIKE, U. M. and ANAGOR, T. A., 2013b. Morphology of the oropharynx and tongue of the muscovy duck (Anas Platyrhynchos). Veterinarski Arhive, vol. 83, no. 6, pp. 685-693.

IWASAKI, S. and KOBAYASHI, K., 1986. Scanning and transmission electron microscopy studies on the lingual dorsal epithelium of chickens. Kaibogaku zasshi. Journal of anatomy, vol. 61, no. 2, pp. 83-96. PMid:3751494.

IWASAKI, S., 1992. Fine structure of the dorsal lingual epithelium of the little tern, Sterna albifrons Pallas (Aves, Lari). Journal of Morphology, vol.212, no. 1, pp. 13-26. http://dx.doi.org/10.1002/ jmor.1052120103. PMid:1375296.

IWASAKI, S., 2002. Evolution of the structure and function of the vertebrate tongue. Journal of Anatomy, vol. 201, no. 1, pp. 1-13. http://dx.doi.org/10.1046/j.1469-7580.2002.00073.x. PMid:12171472.

IWASAKI, S., ASAMI, T. and CHIBA, A., 1997. Ultrastructural study of the keratinization of the dorsal epithelium of the tongue of Midden dorff's bean goose, Anser fabalis middendorffii (Anseres, Anatidae). The Anatomical Record, vol. 247, no. 2, pp. 149-163. http://dx.doi.org/10.1002/(SICI)10970185(199702)247:2<149::AID-AR1>3.0.CO;2-T. PMid:9025994.

JACKOWIAK, H. and GODYNICKI, S., 2005. Light and Scanning Electron Microscope study of the tongue in white tailed eagle, Haliaeetus albicilla (Accipitridae, Aves). Annals of Anatomy, vol. 198, no. 3, pp. 251-259. http://dx.doi.org/10.1016/j. aanat.2004.11.003. PMid:16130824.

JACKOWIAK, H. and LUDWIG, M., 2008. Light and scanning electron microscopic study of the structure of the ostrich (Strutiocamelus) tongue. Zoological Science, vol. 25, no. 2, pp. 188-194. http:// dx.doi.org/10.2108/zsj.25.188. PMid:18533750.

KOOLOS, J., 1986. A conveyer-belt model for pecking in the Mallard, Anas platyhynos. Netherland Journal of Zoology, vol. 36, pp. 47-87.

MCLELLAND, J., 1975. Aves digestive system. In: R. GETTY, ed. Sisson and Grossman's the anatomy of the domestic animals. 5th ed. Philadelphia: Saunders Company, vol. 2.

PARCHAMI, A., DEHKORDI, R.A.F. and BAHADORAN, S., 2010. Fine structure of the dorsal lingual epithelium of the common quail (Coturnix coturnix). World Applied Science, vol.J10, pp. 1185-1189. 
SHAWKI, N. A. and ABDEL-RAHMAN, G. H., 1998. The functional morphology of the lingual apparatus of the cattle egret, Bubulcus ibis. Journal of Union Arab of Biology, vol. 9(A), pp. 191-221.

SKIERESZ-SZEWCZYK, K., JACKOWIAK, H. and RATAJCZAK, M., 2014. LM and TEM study of the orthokeratinized and parakeratinized epithelium of the tongue in the domestic duck (Anas platyrhynchosf. domestica). Micron (Oxford, England: 1993, vol. 67, pp. 117-124. http://dx.doi.org/10.1016/j.micron.2014.07.004 PMid:25137178.
TAKI-EL-DEEN, F.M.A., 2017. Comparative Microscopic study on the tongue, oesophagus and stomach of two different birds in egypt. The Egyptian Journal of Hospital Medicine, vol. 67, no. 1, pp. 359-365. http://dx.doi.org/10.12816/0036649.

TIVANE, C. 2008. A morphological study of the oropharynx and oesophagus of the ostrich (Struthio camelus). Pretoria: University of Pretoria. Masters Dissertation.

WHITTOW, G.C., 2000. Sturkie's avian physiology. London: Academic Press. 